\title{
PENGARUH STRES KERJA, KOMITMEN ORGANISASIONAL, DAN GAYA KEPEMIMPINAN TERHADAP KEPUASAN KERJA KARYAWAN
}

\author{
Nisa Meitasari Gunawan ${ }^{1}$ \\ AA. Ayu Sriathi² \\ ${ }^{1,2}$ Fakultas Ekonomi dan Bisnis Universitas Udayana (Unud), Bali, Indonesia \\ email: meitasarinisa@gmail.com
}

\begin{abstract}
ABSTRAK
Tujuan penelitian ini adalah untuk menganalisis pengaruh stres kerja, komitmen organisasional, dan gaya kepemimpinan terhadap kepuasan kerja karyawan. Populasi pada penelitian ini adalah seluruh karyawan berjumlah 137 orang. Pendekatan Slovin digunakan untuk menghitung sampel yang berjumlah 58 responden dan menggunakan probability sampling sebagai metode pengumpulan sampel. Data di analisis menggunakan teknik analisis regresi linier berganda. Hasil analisis data menunjukkan bahwa stres kerja berpengaruh negatif terhadap kepuasan kerja karyawan, komitmen organisasional berpengaruh positif terhadap kepuasan kerja karyawan, dan gaya kepemimpinan berpengaruh positif terhadap kepuasan kerja karyawan. Kepuasan kerja karyawan dapat ditingkatkan dengan memperhatikan dan stres kerja, komitmen organisasional serta gaya kepemimpinan dalam organisasi. Organisasi diharapkan agar memperbaiki tigkat stres kerja, meningkatkan komitmen organisasional dan gaya kepemimpinan yang telah diterapkan di dalam organisasi.

Kata Kunci: stres kerja, komitmen oranisasional, gaya kepemimpinan, kepuasan kerja karyawan.
\end{abstract}

\begin{abstract}
The purpose of this study was to analyze the effect of work stress, organizational commitment, and leadership style on employee job satisfaction. The population in this study were all employees totaling 137 people. The Slovin approach is used to calculate a sample of 58 respondents and uses probability sampling as a sample collection method. The data were analyzed using multiple linear regression analysis techniques. The results of data analysis show that work stress negatively affects employee job satisfaction, organizational commitment has a positive effect on employee job satisfaction, and leadership style has a positive effect on employee job satisfaction. Employee job satisfaction can be increased by paying attention to and stressful work, organizational commitment and leadership style in the organization. The organization is expected to improve the level of work stress, improve organizational commitment and leadership style that has been applied in the organization.

Keywords: job stress, organizational commitment, leadership style, employee job satisfaction.
\end{abstract}




\section{PENDAHULUAN}

Sumber daya manusia memengaruhi tercapainya suatu tujuan perusahaan. Mengelola sumber daya manusia dalam suatu organisasi bukan hal yang mudah, karena dalam organisasi melibatkan berbagai elemen, yaitu karyawan, pimpinan maupun sistem itu sendiri. Perusahaan harus memperhatikan hubungan yang baik antar karyawan dan atasan agar terciptanya kepuasan kerja (Sutrisno, 2014:75). Kepuasan kerja memiliki peranan yang penting bagi organisasi, karena kepuasan kerja merupakan kriteria dalam menentukan keberhasilan suatu organisasi untuk memenuhi kebutuhan anggotanya.

Menurut Sinambela (2016:302) kepuasan kerja karyawan adalah seperangkat perasaan pegawai tentang menyenangkan atau tidaknya pekerjaan mereka. Oleh karena itu kepuasan kerja di suatu perusahaan sangatlah penting, sebab pada dasarnya kepuasan kerja karyawan memiliki tingkat kepuasan yang berbeda-beda karena suatu kepuasan bersifat individu dan sesuai dengan karakteristik yang berlaku pada dirinya. Handoko (2014:193) menyatakan kepuasan kerja adalah keadaan emosional yang menyenangkan atau tidak menyenangkan para karyawan memandang pekerjaan mereka. Shurbagi (2014) berpendapat bahwa kepuasan kerja merupakan cara pandang seseorang baik yang bersifat positif maupun negatif tentang pekerjaannya. Zainal dkk. (2014:246), menyatakan bahwa kepuasan kerja adalah penilaian dari pekerja tentang seberapa jauh pekerjaannya secara keseluruhan memuaskan kebutuhannya.

Menurut Dhania (2010) faktor-faktor yang memengaruhi kepuasan kerja salah satunya adalah stres kerja. Velnampy dan Aravinthan (2013) menyatakan 
bahwa stres kerja adalah pola emosional perilaku kognitif dan reaksi psikologis terhadap aspek yang merugikan dan berbahaya dari setiap pekerjaan, organisasi kerja dan lingkungan kerja. Tantangan-tantangan dalam pekerjaan tidak ada jika seseorang tidak memiliki tingkat stres, sedangkan meningkatnya stres membantu karyawan untuk mengarahkan segala sumber daya dalam memenuhi bebagai persyaratan atau kebutuhan pekerjaan dan mendorong para karyawan memberikan tanggapan terhadap tantangan-tantangan pekerjaan (Handoko 2014 : 202). Stres yang terlalu tinggi menyebabkan kepuasaan kerja mulai menurun karena stres mengganggu pelaksanaan pekerjaan yang dapat membuat karyawan tidak mampu mengambil keputusan dan perilaku menjadi tidak teratur (Umar 2012 : 265). Adapun hubungan antara stres kerja dengan kepuasan kerja,penelitian yang dilakukan oleh Styawahyuni (2014) menemukan hasil bahwa stres kerja berpengaruh negatif dan signifikan terhadap kepuasan kerja karyawan, nilai negatif menandakan semakin karyawan merasa stres terhadap pekerjaannya maka kepuasaan kerjanya akan menurun sedangkan bila stres kerja yang dialami oleh karyawan rendah maka kepuasan kerjanya akan semakin meningkat.

Organisasi harus membuat suasana kerja yang nyaman agar dapat meningkatkan komitmen karyawan dalam berorganisasidi perusahaan. Perusahaan tidak akan mencapai tujuannya jika tidak ada usaha dan komitmen dari karyawannya. Peran organisasi sangat diperlukan untuk membentuk komitmen karyawannya, organisasi dituntut untuk mampu memberikan dukungan kepada karyawannya. Menurut Murty dan Gunasti (2013), karyawan yang memiliki komitmen organisasional adalah karyawan yang mampu mengidentifikasi 
keterlibatan dirinya dalam organisasi. Seorang karyawan harus mempunyai komitmen yang tinggi pada organisasinya agar dapat bekerjasama dan berprestasi dengan baik,. Komitmen dapat tumbuh manakala harapan kerja dapat terpenuhi oleh organisasi dengan baik. Selanjutnya dengan terpenuhinya harapan kerja ini menimbulkan kepuasan kerja.

Suatu komitmen menggambarkan keterikatan seseorang di dalam suatu organisasi, sehingga menimbulkan suatu rasa ikut memiliki (sense or belonging) terhadap organisasi tempat ia bekerja. Memiliki rasa untuk ikut memiliki tersebut sesorang akan dengan tidak berat hati dalam melakukan pekerjaannya sehingga, mereka akan dengan mudah merasakan kepuasan kerja dari pekerjaan yang mereka kerjakan.Hubungan antara variabel komitmen organisasional dengan kepuasan kerja, menurut penelitian Rimata (2014) menemukan hasil bahwa komitmen organisasional berpengaruh positif dan signifikan terhadap kepuasan kerja.

Hasibuan (2014 : 203) menyatakan salah satu faktor yang memengaruhi kepuasan kerja adalah sikap pimpinan dalam memimpin. Pemimpin sebagai panutan dalam organisasi, sehingga perubahan harus dimulai dari tingkat yang paling atas yaitu pemimpin itu sendiri. Maka dari itu, organisasi memerlukan pemimpin reformis yang mampu menjadi motor penggerak yang mendorong perubahan organisasi. Sampai saat ini, kepemimpinan masih menjadi topik yang menarik untuk dikaji dan diteleti, karena paling sering diamati namun merupakan fenomena yang sedikit dipahami. Hubungan variabel antara gaya kepemimpinan dengan kepuasan kerja, menurut penelitian yang dilakukan oleh Fajriyah dan 
Prasetya (2015) menyatakan bahwa Gaya Kepemimpinan berpengaruh positif terhadap Kepuasan Kerja yang berarti karyawan akan lebih semangat dalam menjalankan tugas serta kewajibannya dan akan meningkatkan kemampuan karyawan dalam bekerja.

Penelitian ini dilakukan di Hotel Novotel Bali Ngurah Rai Airport yang berlokasi di Bandar Udara Internasional I Gusti Ngurah Rai dengan akses langsung ke Keberangkatan Internasional dan Kedatangan Domestik. Berdasarkan wawancara awal yang dilakukan terhadap 7 orang karyawan yang berada di departemen keuangan yang terdiri dari 5 orang karyawan tetap dan 2 orang karyawan tidak tetap di Hotel Novotel Bali Ngurah Rai Airport terdapat beberapa permasalahan yang berindikasi memengaruhi rendahnya kepuasan karyawan. Permasalah pertama yaitu tanggung jawab yang dipikul oleh para karyawan belum sesuai dengan gaji pokok yang diterima. Permasalahan kedua yaitu masih rendahnya komitmen karyawan di karenakan tidak semua karyawan mempunyai rasa memiliki terhadap perusahaan dan belum bersedia melakukan apapun demi kemajuan organisasi. Permasalahan yang terakhir yaitu karyawan kurang beranggapan apabila bekerja di organisasi ini adalah kesempatan yang baik karena merasa kurangnya pengawasan dari pimpinan.

Two factor theory menjelaskan bahwa kepuasan kerja berbeda dengan ketidakpuasan kerja (Hezberg, 1959) dalam Priansa (2014). Artinya kepuasan dan ketidakpuasan terhadap pekerjaan itu tidak merupakan suatu variabel yang berkelanjutan. Dua faktor yang dapat menimbulkan rasa puas atau tidak puas menurut Herzberg adalah hygiene factor dan faktor motivasi, namun yang 
digunakan dalam mengukur kepuasan dalam organisasi hanya satu faktor yaitu hygiene factor, dimana hygiene factoradalah faktor-faktor yang dapat menyebabkan atau mencegah ketidakpuasan dalam bekerja. Faktor ini adalah faktor intrinsik yang antara lain : kepuasan terhadap pekerjaan, kepuasan terhadap atasan, kepuasan terhadap gaji, kepuasan terhadap rekan kerja, dan kepuasan terhadap promosi.

Zainal dkk. (2014:246) menyatakan bahwa kepuasan kerja adalah penilaian dari pekerja tentang seberapa jauh pekerjaan dapat membuatnya tetap bertahan di perusahaan yang secara keseluruhan untuk memuaskan kebutuhannya. Menurut Malik et al. (2012) kepuasan kerja dalam menjalankan fungsinya tidak berdiri sendiri, tetapi berhubungan dengan kinerja dan tingkat imbalan, dipengaruhi oleh keterampilan, kemampuan, dan sifat-sifat individu. Kepuasan kerja merupakan evaluasi yang menggambarkan seseorang atas perasaan sikap senang atau tidak senang, puas atau tidak puas dalam bekerja.

Handoko $(2014 ; 193)$ menyatakan kepuasan kerja adalah keadaan emosional yang menyenangkan atau tidak menyenangkan para karyawan memandang pekerjaan mereka. Kepuasan kerja menurut(Robbins \& Judge, 2017) merupakan sikap umum seorang individu atau karyawan terhadap pekerjaannya. Seorang dengan tingkat kepuasan kerja tinggi menunjukan sikap yang positif terhadap pekerjaannya, sebaliknya seorang yang tidak puas akan menunjukan sikap yang negatif terhadap pekerjaannya.

Menurut Fauji (2013) Stres kerja merupakan suatu kondisi yang merefleksikan rasa tertekan, tegang yang mempengaruhi emosi dan proses berfikir 
seorang karyawan untuk mengerjakan pekerjaannya sehingga menghambat tujuan organisasi. Menurut Handoko (2014:200), stres kerja adalah suatu kondisi ketegangan yang memengaruhi proses berpikir, emosi, dan kondisi seseorang, hasilnya stres yang terlalu berlebihan dapat mengancam kemampuan seseorang untuk menghadapi lingkungan dan pada akhirnya akan mengganggu pelaksanaan tugas-tugasnya. Beloor et al. (2017) menyatakan bahwa pekerjaan harus dipelihara secara efektif untuk memastikan bahwa semua karyawan bekerja pada potensinya masing-masing dan bebas dari stres. Karena menurut Afrizal dkk. (2014) berpendapatbahwa karyawan yang stres cenderung menganggap suatu pekerjaan bukanlah sesuatu yang penting bagi mereka, sehingga tidak mampu menyelesaikan suatu pekerjaan tersebut sesuai target yang telah ditetapkan.

Komitmen adalah sikap kesediaan diri untuk memegang teguh visi, misi serta kemauan untuk mengerahkan seluruh usaha dalam melaksanakan tugas. Komitmen karyawan tidak akan tumbuh dengan sendirinya, ada hubungan signifikan antara budaya kerja dengan komitmen karyawan (Robbins \& Judge, 2017). Menurut Spagnoli dan Antonio (2012) komitmen organisasional yang baik dapat menghindari terjadinya perilaku kerja menyimpang yang dilakukan oleh karyawan sehingga dapat mencegah karyawan untuk keluar dari perusahaan yang tentunya mengganggu rutinitas dari organisasi. Karyawan akan merasa bahwa organisasi adalah tempat untuk memenuhi kebutuhan personal mereka sehingga mereka bersedia mengerahkan kemampuan maksimalnya demi berkontribusi terhadap organisasi, dengan demikian perlahan akan menimbulkan kepuasan dari apa yang telah mereka lakukan untuk organisasi. 
Menurut Meyer dan Allen (1997), ada tiga komponen komitmen organisasi yaitu: 1) Komitmen normatif (normative). Definisi ini mengandung pengertian bahwa individu merasa memiliki kewajiban untuk tetap menjadi anggota organisasi. Karyawan yang memiliki tingkat komitmen normatif tinggi merasa bahwa mereka seharusnya atau sepatutnya (ought to) tetap tinggal dalam organisasinya. 2) Komitmen berkesinambungan (continuance). Komitmen berkesinambungan mengacu pada kesadaran atas kerugian yang akan ditanggungnya bila meninggalkan organisasinya. Karyawan yang memiliki komitmen berkesinambungan kuat dasarnya adalah mereka mempunyai kebutuhan untuk melakukannya (need to). 3) Komitmen afektif (affective). Di dalam komitmen afektif ada ikatan emosional karyawan kepadaorganisasinya, yang dinyatakan dengan identifikasi, dan keterlibatan dalam kegiatan-kegiatan organisasi. Karyawan yang memiliki komitmen afektif kuat akan melanjutkan keanggotaannya dengan organisasi karena mereka ingin melakukannya (wants to).

(Robbins \& Judge, 2017)pemimpin adalah orang yang mempunyai tugas untuk mengarahkan dan membimbing bawahan dan mampu memperoleh dukungan bawahan sehingga dapat menggerakkan bawahan ke arah pencapaian tujuan organisasi. Kepemimpinan adalah kemampuan untuk memengaruhi suatu kelompok menuju pencapaian sebuah visi atau tujuan yang ditetapkan. Zainal dkk. (2014:42) gaya kepemimpinan adalah sekumpulan ciri yang digunakan pimpinan untuk memengaruhi bawahan agar sasaran organisasi tercapai.Ardana dkk (2012:181) mengemukakan gaya kepemimpinan ialah pola perilaku yang akan ditunjukkan oleh pemimpin dalam memengaruhi orang lain atau karyawan. 
Pendekatan yang digunakan untuk membedakan kepemimpinan. Salah satunya yang umum dikenal adalah yang menyatakan bahwa para pemimpin pada dasarnya dapat di kategorikan menjadi lima tipe menurut Djatmiko yang dikutip oleh Ardana dkk (2012:97) adalah pertama tipe otokratik,ciri-cirinya antara lain mengambil keputusan sendiri, memusatkan kekuasaan dan pengambilan keputusan pada dirinya, bawahan melakukan apa sepenuhnya dan biasanya berorientasi pada kekuasaan. Kedua tipe paternalistik,ciri-cirinya antara lain mengambil keputusan cenderung menggunakan cara sendiri tanpa melibatkan, hubungan dengan bawahan bersifat bapak-anak, berusaha memenuhi kebutuhan fisik anak buah untuk mencari perhatian dan tanggung jawab mereka, serta berorientasinya dalam menjaga hubungan yang baik dengan bawahan. Ketiga tipe karismatis,ciri-cirinya diantaranya memelihara hubungan dengan bawahan agar pelaksanaan tugas dapat terseleggara dengan baik sekaligus memberi kesan bahwa hubungan tersebut berbasis pada relasionalitas bukan kekuasaan. Keempattipe laisses faire (free reign), ciri-cirinya antara lain menghindari penumpukan kekuasaan dengan jalan mendelegasikan kepada bawahan, tergantung pada kelompok dalam menentukan tujuan dan penyelesaian masalah, serta akan menjadi efektif apabila di lingkungan profesional yang bermotivasi tinggi. Kelimatipe demokratis (partisipatif), ciri-cirinya antara lain membagi tanggung jawab pengambilan keputusan dengan kelompok, mengembangkan tanggungjawab kelompok untuk menyelesaikan tugas, memakai pujian dan kritik meski pengembilan keputusan dilimpahkan, namun tanggung jawab tetap kepada pimpinan. 
Hasibuan (2014:107) ada dua gaya kepemimpinan yang biasa digunakan oleh seorang pemimpin dalam mengarahkan atau memegaruhi bawahan sebagai berikut. 1) Gaya kepemimpinan yang berorientasi pada tugas (Task Oriented Style).Gaya kepemimpinan ini, memprioritaskan seorang manajer akan mengarahkan dan mengawasi bawahannya serta ketat dalam melaksanakan tugas dan menekankan pentingnya melaksanakan tugas seoptimal mungkin agar hasilnya sesuai dengan harapan manajer. Manajer dengan gaya ini lebih mengutamakan keberhasilan pekerjaan daripada pengembangan kemampuan bawahan. 2) Gaya kepemimpinan yang berorientasi pada pekerja (Employee Oriented Style). Manajer dengan gaya ini berusaha mendorong dan memotivasi bawahannya untuk bekerja dengan baik. Mereka mengikutsertakan bawahan dalam pengambilan keputusan yang menyangkut tugas atau pekerjaan bawahan. Hubungan pemimpin dan bawahan terasa sangat akrab, saling percaya dan saling menghargai.

Stres adalah tanggapan psikologis dari seseorang terhadap tekanan dari lingkungannya, dimana penekannya berupa peristiwa atau situasi eksternal yang dapat membahayakan. Dari hasil-hasil penelitian sebelumnya ditemukan oleh Afrizal dkk. (2014) menunjukkan bahwa stres kerja berpengaruh negatif dan signifikan terhadap kepuasan kerja. Dewi dkk. (2014) menyatakan ada hubungan negatif dan signifikan stres kerja terhadap kepuasaan kerja karyawan. Wibowo dkk. (2015) menyatakan stres kerja memiliki pengaruh negatif terhadap kepuasan kerja. Hal ini berarti kepuasan kerja akan meningkat jika tingkat stres kerja 
karyawan rendah. Maka, semakin rendah stres kerja yang dirasakan karyawan, maka semakin tinggi pula kepuasan kerja karyawan.

Dari hasil-hasil penelitian sebelumnya ditemukan oleh Afrizal dkk. (2014) menunjukkan bahwa stres kerja berpengaruh negatif dan signifikan terhadap kepuasan kerja. Dewi dkk. (2014) dan Dewi (2016) menyatakan ada hubungan negatif dan signifikan stres kerja terhadap kepuasaan kerja karyawan. Wibowo dkk. (2015) dan Pratama (2018) menyatakan stres kerja memiliki pengaruh negatif terhadap kepuasan kerja.Hal ini berarti kepuasan kerja akan meningkat jika tingkat stres kerja karyawan rendah. Maka, semakin rendah stres kerja yang dirasakan karyawan, maka semakin tinggi pula kepuasan kerja karyawan.

$\mathrm{H}_{1}$ : Stres kerja berpengaruh negatif terhadap kepuasan kerja karyawan

Komitmen organisasional merupakan suatu keadan di mana karyawan memihak dan perduli pada organisasi tertentu dengan tujuan-tujuannya serta berniat memelihara keanggotaannya dalam organisasi tersebut. Baraba dkk. (2014) dalam penelitiannya yang bertujuan untuk menguji pengaruh komitmen organisasional terhadap kepuasan kerja, menemukan hasil bahwa komitmen organisasional berpengaruh negatif terhadap kepuasan kerja karyawan. Okubanjo (2014) dalam penelitiannya untuk menguji kekuatan prediksi dari komitmen organisasional terhadap kepuasan kerja karyawan menemukan hubungan yang signifikan antara komitmen dan kepuasan kerja karyawan. Arifah dan Romadhon (2015) bertujuan untuk menguji komitmen organisasional, komitmen professional dan gaya kepemimpinan yang berpengaruh terhadap kepuasan kerja karyawan menemukan hasil bahwa komitmen organisasional berpengaruh positif dan 
signifikan terhadap kepuasan kerja karyawan. Hal ini berarti, kepuasan kerja karyawan akan meningkat jika karyawan merasa puas akan rasa komitmen organisasional yang dimilikinya. Maka, semakin baik komitmen organisasional yang dimiliki karyawan, maka semakin tinggi pula kepuasan kerja karyawan.

$\mathrm{H}_{2}$ : Komitmen organisasional berpengaruh positif terhadap kepuasan kerja karyawan

Gaya kepemimpinan adalah pola perilaku atau cara yang dipilih dan dipergunakan pemimpin dalam memengaruhi pikiran, perasaan, sikap, dan perilaku para anggota bawahannya agar mau bekerja sama untuk mencapai tujuan organisasi.Penelitian yang dilakukan oleh Safitri dkk. (2012) mengenai pengaruh gaya kepemimpinan terhadap kepuasan kerja perawat pada industri kesehatan di Malaysia menunjukkan hasil bahwa gaya kepemimpinan berpengaruh signifikan terhadap kepuasan kerja. Arzi dan Farahbod (2014) pada penelitiannya menemukan hasil bahwa gaya kepemimpinan memiliki pengaruh yang signifikan terhadap kepuasan kerja. Machumu dan Kaitila (2014) melakukan penelitian terhadap guru mengenai pengaruh gaya kepemimpinan terhadap kepuasan kerja dan mendapatkan hasil yang menunjukkan gaya kepemimpinan berpengaruh positif dan signifikan terhadap kepuasan kerja. Plangiten (2013) dalam penelitiannya mengenai gaya kepemimpinan dan pengaruhnya terhadap kepuasan kerja mendapatkan hasil bahwa gaya kepemimpinan berpengaruh terhadap kepuasan kerja. Hal ini berarti, kepuasan kerja akan meningkat jika karyawan merasa puas akan gaya kepemimpinan yang diterapkan perusahaan. Maka, semakin baik gaya kepemimpinan yang diterapkan kepada karyawan, maka semakin tinggi pula kepuasan kerja karyawan. 
Nisa Meitasari Gunawan, Pengaruh Stres Kerja....

$\mathrm{H}_{3}$ : Gaya kepemimpinan berpengaruh positif terhadap kepuasan kerja karyawan

\section{METODE PENELITIAN}

Lokasi penelitian ini bertempat di Hotel Novotel Bali Ngurah Rai Airport. Alasan peneliti melakukan penelitian di Hotel Novotel Bali Ngurah Rai Airport karena pemilihan lokasi ini didasari atas tersedianya data yang memadai dan mampu untuk diolah peneliti lebih lanjut dan adanya masalah tentang kepuasan kerja karyawan.

Populasi penelitian ini adalah seluruh karyawan Populasi penelitian ini adalah seluruh pegawai di Novotel bali Ngurah Rai Airport yang berjumlah 137 orang. Pegawai tetap pada perusahaan ini berjumlah 81 orang, pegawai harian berjumlah 31 orang, sedangkan training berjumlah 25 orang. Teknik sampel yang digunakan dalam penelitian ini adalah probability sampling karena kerangka sampelnya sudah diketahui seperti jumlah karyawan, sedangkan metode penentuan sampel yang digunakan dalam penelitian ini mengacu pada pendekatan Slovin(Sugiyono, $2013: 78$ ).

$$
n=\frac{\mathrm{N}}{N \cdot d^{2}+1}
$$

Dimana :

$\mathrm{n}=$ Jumlah sampel

$\mathrm{N}=$ Jumlah populasi

$\mathrm{d}=$ Persentase kelonggaran kesalahan pengambilan sampel yang masihdapat ditolerir, dalam penelitian ini digunakan persentase kesalahan $10 \%$.

Besarnya populasi yaitu sebesar 137 orang. Jadi besarnya sampel yang harus dicapai dalam penelitian ini adalah sebesar : 


$$
n=\frac{\mathrm{N}}{N \cdot d^{2}+1}=\frac{137}{\left(137 \cdot 0,1^{2}\right)+1}=\frac{137}{2,37}=57,8
$$

Berdasarkan rumus slovin di atas, sampel yang dapat diambil dari populasi yang besar yaitu sebanyak 57,8 orang, karena sampel dalam penelitian ini adalah karyawan maka jumlah sampel dibulatkan menjadi 58 responden.

\section{Tabel 1.}

Data jumlah populasi dan sampel Hotel Novotel Bali Ngurah Rai Aiport

\begin{tabular}{llll}
\hline NO & Jenis Pegawai & $\begin{array}{l}\text { Populasi } \\
\text { (orang) }\end{array}$ & Sampel (orang) \\
\hline 1. & Pegawai Tetap & 81 & 34 \\
2. & Daily Worker (Pekerja Harian) & 31 & 13 \\
3. & Training & 25 & 11 \\
& Total & $\mathbf{1 3 7}$ & $\mathbf{5 8}$ \\
\hline
\end{tabular}

Sumber: Hotel Novotel Bali Ngurah Rai Airport, 2018

Model analisis yang digunakan dalam penelitian ini adalah analisis regresi linear berganda dengan menggunakan bantuan aplikasi SPSS (Statistical Package for Social Science) versi 17.0.Adapun model analisis dari Regresi Berganda yang dimaksud adalah sebagai persamaan berikut :

$$
Y=a+\beta_{1} X_{1}+\beta_{2} X_{2}+\beta_{3} X_{3}+\varepsilon
$$

Dimana :

$$
\begin{array}{ll}
\mathrm{Y} & =\text { Kepuasan Kerja } \\
a & =\text { Koefisien Konstanta } \\
\beta & =\text { Koefisien regresi dari masing-masing variabel } \\
\mathrm{X}_{1} & =\text { Stres kerja } \\
\mathrm{X}_{2} & =\text { Komitmen organisasional } \\
\mathrm{X}_{3} & =\text { Gaya kepemimpinan } \\
\varepsilon & =\text { Error }
\end{array}
$$

\section{HASIL PENELITIAN DAN PEMBAHASAN}

Data karakteristik responden adalah data responden yang dikumpulkan untuk mengetahui profil responden penelitian. Berdasarkan hasil penelitian yang 
dilakukan terhadap karyawan Hotel Novotel Bali Ngurah Rai Airport dapat diketahui karakteristik responden meliputi jenis kelamin, usia, pendidikan terakhir, dan lama bekerja.

Tabel 2.

\begin{tabular}{|c|c|c|c|c|}
\hline $\mathbf{K a}$ & akteristik Res & I Karyawaı & tel Bali N & Rai Air \\
\hline No & Karakteristik & & Frekuensi & $\begin{array}{l}\text { Persentase } \\
\text { (\%) }\end{array}$ \\
\hline 1 & & Laki-Laki & 38 & 65,5 \\
\hline & Jenıs Kelamın & Wanita & 20 & 34,5 \\
\hline & Total & & 58 & 100 \\
\hline & & $\leq 20$ th & 15 & 25,9 \\
\hline 2 & Usia & $21-30$ th & 35 & 60,3 \\
\hline & & $31-40$ th & 8 & 13,8 \\
\hline & Total & & 58 & 100 \\
\hline & & $<1$ tahun & 23 & 39,7 \\
\hline 3 & Masa Kerja & $1-2$ tahun & 18 & 31 \\
\hline & & $2-3$ tahun & 17 & 29,3 \\
\hline & Total & & 58 & 100 \\
\hline & & SMP & 6 & 10,3 \\
\hline & & SMA/SMK & 13 & 22,4 \\
\hline 4 & Pendidikan & Diploma & 29 & 50 \\
\hline & & Sarjana & 10 & 17,2 \\
\hline & Total & & 58 & 100 \\
\hline & & Tetap & 34 & 58,6 \\
\hline 5 & Jenis Karyawan & Tidak Tetap & 24 & 41,4 \\
\hline & Total & & 58 & 100 \\
\hline
\end{tabular}

Sumber: Data diolah, 2018

Berdasarkan pada Tabel 2. responden yang berjenis kelamin laki-laki dengan jumlah responden 38 orang atau 65,5 persen dari total responden lebih banyak dibandingkan dengan yang berjenis kelamin perempuan, ini berarti di Hotel Novotel Bali Ngurah Rai Airport, lebih mengutamakan karyawan yang berjenis kelamin laki-laki karena banyaknya pekerjaan yang lebih membutuhkan tenaga laki-laki. Responden paling banyak adalah yang berusia 21-30 tahun dengan jumlah responden 35 orang atau 60,3 persen, ini berarti di Hotel Novotel Bali Ngurah Rai Airport lebih mengutamakan karyawan yang berada pada usia produktif. Dilihat dari klasifikasi profil responden berdasarkan masa kerja, karyawan dengan masa kerja $<1$ tahun sebanyak 23 orang atau 39,7 persen adalah 
yang paling banyak dan berdasarkan pendidikan, maka dapat dilihat dari responden yang berpendidikan Diploma paling banyak dengan jumlah responden 29 orang atau 50 persen dari total responden dikarenakan Hotel Novotel Bali Ngurah Rai Airport sering merekrut karyawan tidak tetap seperti training dan daily worker. Berdasarkan jenis karyawan, jenis karyawan tetap yang sedikit lebih banyak dengan jumlah responden 34 atau 58,6 persen dari total responden karena para karyawan tersebut melaui perekrutan saat pembukaan Hotel atau telah menjadi daily worker lebih dari 1 tahun.

Uji asumsi klasik dilakukan untuk menguji kelayakan model yang dibuat sebelum digunakan untuk memprediksi. Adapun uji asumsi klasik meliputi: uji normalitas, uji multikolinearitas dan uji heteroskedastisitas.

Setelah melakukan uji normalitas data pada variabel stres kerja, komitmen organisasional, gaya kepemimpinan dan kepuasan kerja karyawan menggunakan Uji Kolmogorov-Smirnov maka didapatkan hasil sebagai berikut:

Tabel 3.

Hasil Uji Kolmogorov-Smirnov

\begin{tabular}{cl}
\hline & Unstandardized Residual \\
\hline Asymp. Sig (2-tailed) & 0,615 \\
\hline Sumber: Data diolah, 2018 &
\end{tabular}

Berdasarkan Tabel 3. dapat dilihat bahwa hasil Asymp. Sig (2-tailed) 0,615 $>0,050$ maka data yang digunakan dalam penelitian bersifat normal.

Setelah melakukan Uji Heteroskedastisitas dengan Uji Gletjer, terhadap variabel Stres Kerja, Komitmen Organisasional, Gaya Kepemimpinan terhadap Kepuasan Kerja Karyawa maka didapatkan hasil sebagai berikut: 
Tabel 4.

Hasil Uji Heteroskedastisitas dengan Uji Gletjer

\begin{tabular}{cc}
\hline Variabel & Sig \\
\hline Stres Kerja & 0,807 \\
Komitmen Organisasional & 0,836 \\
Gaya Kepemimpinan & 0,288 \\
\hline
\end{tabular}

Sumber: Data diolah, 2018

Model regresi yang baik adalah yang mempunyai nilai $\operatorname{Sig}>0,05$. Dari hasil Uji Heteroskedastisitas dengan Uji Gletjer diatas maka dapat dilihat dilai Sig dari masing-masing variabel $>0,05$ yang artinya tidak terjadi heteroskedastisitas, atau tidak ada penyimpangan/ ketidaksamaan varian dari residual untuk semua pengamatan pada model regresi.

Setelah melakukan Uji Multikolinieritas terhadap variabel Stres Kerja, Komitmen Organisasional, dan Gaya Kepemimpinan terhadap Kepuasan Kerja maka didapatkan hasil sebagai berikut:

Tabel 5.

Hasil Uji Multikolonieritas

\begin{tabular}{llc}
\hline \multicolumn{1}{c}{ Variabel } & Tolerance & VIF \\
\hline Stres Kerja & 0,644 & 1,554 \\
Komitmen Organisasional & 0,467 & 2,142 \\
Gaya Kepemimpinan & 0,628 & 1,592 \\
\hline
\end{tabular}
Sumber: Data diolah, 2018

Dari hasil Uji Multikolinieritas maka dapat dilihat nilai Tolerance pada masing-masing variabel diatas $>0,10$. Sementara itu, nilai VIF pada masingmasing variebel diatas $<10,00$ sehingga dapat disimpulkan tidak terjadi Multikolinieritas, atau tidak terjadi hubungan antara variabel bebas dalam model regresi.

Analisis regresi linear berganda bertujuan untuk mengetahui ketergantungan suatu variabel terikat dengan satu atau lebih variabel bebas. Analisis ini juga dapat menduga arah dari hubungan tersebut serta mengukur derajat keeratan hubungan 
antara satu variabel terikat dengan satu variabel bebas. Adapun hasil analisis regresi dengan program statitical pacage of social science (SPSS) dapat dilihat pada Tabel 6. berikut.

Tabel 6.

Rangkuman Hasil Analisis Regresi Linear Berganda

\begin{tabular}{|c|c|c|c|c|c|c|}
\hline \multirow{2}{*}{\multicolumn{2}{|c|}{ Model }} & \multicolumn{2}{|c|}{ Unstandardized Coefficients } & \multirow{2}{*}{$\begin{array}{c}\text { Standardized } \\
\text { Coefficients } \\
\text { Beta }\end{array}$} & \multirow[t]{2}{*}{$\mathbf{T}$} & \multirow{2}{*}{ Sig. } \\
\hline & & B & Std. Error & & & \\
\hline \multirow{4}{*}{1} & (Constant) & 7.343 & 2.391 & & 3.071 & .003 \\
\hline & $\mathrm{X} 1$ & -.167 & .066 & -.221 & -2.529 & .014 \\
\hline & $\mathrm{X} 2$ & .301 & .064 & .481 & 4.688 & .000 \\
\hline & $\mathrm{X} 3$ & .273 & .078 & .309 & 3.492 & .001 \\
\hline
\end{tabular}

Dari hasil pada tabel diatas maka dapat dilihat bahwa variabel Stres Kerja (X1), Komitmen Organisasional (X2) dan Gaya Kepemimpinan (X3) dengan nilai Sig. $<0,05$ berpengaruh nyata terhadap variabel Kepuasan Kerja Karyawan (Y). Dari hasil analisis data seperti yang ditunjukkan pada tabel diatas, maka dapatlah dibuat persamaan regresi berganda, yaitu seperti dibawah ini:

$$
Y=7,343-0,167 X_{1}+0,301 X_{2}+0,273 X_{3}
$$

Variabel stres kerja berpengaruh negatif dengan nilai 0,167. Artinya apabila Stres Kerja memberikan berpengaruh terhadap pegawai maka akan semakin menurun Kepuasan Kerja Karyawan di Hotel Novotel Bali Ngurah Rai Airport sebesar 0,167 .

Variabel komitmen organisasional berpengaruh positif dengan nilai 0,301 . Artinya apabila komitmen organisasional memberikan manfaat bagi karyawan maka akan semakin meningkat kepuasan kerja karyawan di Hotel Novotel Bali Ngurah Rai Airport sebesar 0,301.

Variabel gaya kepemimpinan berpengaruh positif dengan nilai 0,273. Artinya apabila gaya kepemimpinan memberikan manfaat bagi karyawan maka 
akan semakin meningkat kepuasan kerja karyawan di Hotel Novotel Bali Ngurah Rai Airport sebesar 0,273.

Uji F digunakan untuk melihat apakah variabel bebas secara bersama-sama mempunyai pengaruh yang signifikan terhadap variabel terikat. Pengujian secara simultan menggunakan distribusi $\mathrm{F}$, yaitu membandingkan antara $\mathrm{F}$ hitung ( $\mathrm{F}$ rasio) dan F tabel. Jika F-hitung < F-tabel, maka $\mathrm{H}_{0}$ diterima, dan jika F-hitung > F-tabel, maka $\mathrm{H}_{0}$ ditolak. Penelitian ini mengunakan tingkat kepercayaan atau confidenceinterval $(\alpha=5 \%)$, jumlah variabel bebas (m) adalah 3 dan jumlah responden (n) adalah 58. Nilai dk pembilang adalah $3 \mathrm{dan}$ dk penyebut adalah 54 (58-3-1), sehingga nilai $\mathrm{F}$-tabel $=\mathrm{F}(\alpha)$ (dk pembilang, $\mathrm{dk}$ penyebut) adalah $\mathrm{F}(\alpha)(3,54)=2,78$

Tabel 7.

Nilai F-Hitung

\begin{tabular}{rllllll}
\hline Model & & Sum of Squares & Df & Mean Square & F & Sig. \\
\hline \multirow{2}{*}{1} & Regression & 304.042 & 3 & 101.347 & 49.764 & $.000^{\mathrm{b}}$ \\
& Residual & 109.975 & 54 & 2.037 & & \\
& Total & 414.017 & 57 & & & \\
\hline
\end{tabular}

Sumber: Data diolah, 2018

Berdasarkan Tabel 7. dapat diketahui bahwa nilai F-hitung $>$ F-tabel yaitu 49,764>2,78 sehingga dapat disimpulkan bahwa $\mathrm{H}_{0}$ ditolak dan $\mathrm{H}_{\mathrm{a}}$ diterima atau dengan kata lain bahwa pada penelitian ini Stres kerja, komitmen organisasional, dan gaya kepemimpinan berpengaruh signifikan terhadap kepuasan kerja karyawan di Novotel Bali Ngurah Rai Airport.

Uji hipotesis pada penelitian ini bertujuan untuk mengetahui seberapa pengaruh variabel bebas terhadap variabel terikat. Pengujian hipotesis pada penelitian ini melalui uji t (uji Parsial). Uji hipotesis digunakan untuk menentukan penerimaan atau penolakan hipotesis $\left(\mathrm{H}_{0}\right)$ menggunakan pengujian signifikansi 
koefisien kolerasi dan uji t. Dalam uji t, apabila nilai thitung lebih besar dari pada nilai tabel, maka hipotesis $\left(\mathrm{H}_{0}\right)$ ditolak. Sedangkan dalam pengujian siginifikansi, apabila tingkat signifikansi lebih kecil dari 0,05 maka hipotesis $\left(\mathrm{H}_{0}\right)$ ditolak.

Nilai $t_{\text {tabel }}$ yang digunakan adalah dengan tingkat kepercayaan sebesar 95\% sehingga $\alpha=5 \%$. Menghiung nilai tabel digunakan ketentuan derajat kebebasan/ degree of freedom $(\mathrm{df})=$ jumlah data -2 . Berdasarkan ketentuan rumus tersebut, maka didapatkan nilai df sebesar 58-2 =56, dengan demikian dapat di hasilkan nilai $t_{\text {tabel }}$ adalah 2,00 dan nilai thitung dapat dilihat di Tabel 8 .

\section{Tabel 8.}

Hasil t-hitung

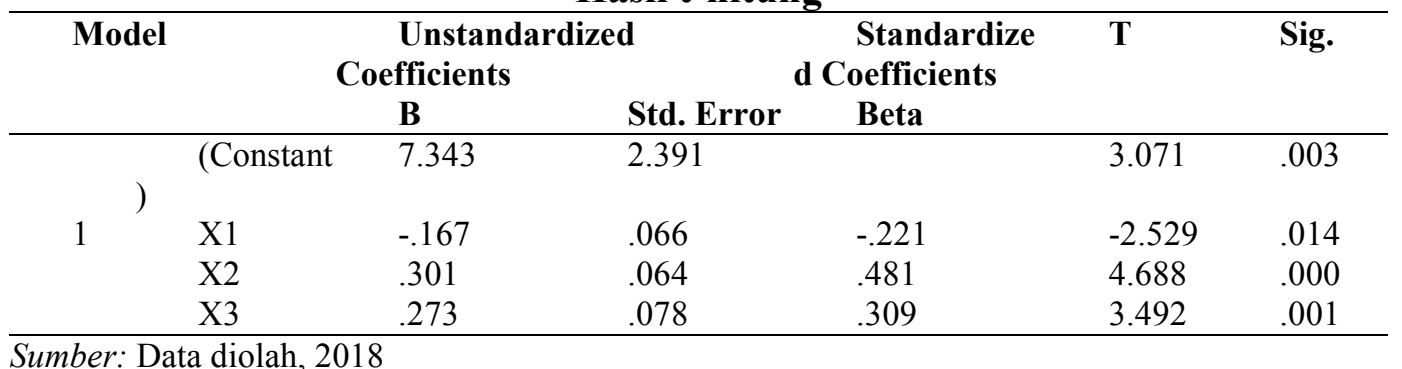

Pada variabel stres kerja diperoleh nilai $t_{\text {hitung }}=2,529$ dan $t_{\text {tabel }}=2,00$. Dapat disimpulkan bahwa $t_{\text {hitung }}$ variabel Stres Kerja lebih besar dari tabel maka H0 ditolak, artinya variabel Stres Kerja berpengaruh negative terhadap variabel kepuasan kerja karyawan di Hotel Novotel Bali Ngurah Rai Airport.

Pada variabel komitmen organisasional diperoleh nilai $t_{\text {hitung }}=4,688$ dan $\mathrm{t}_{\text {tabel }}=2,00$. Dapat disimpulkan bahwa $\mathrm{t}_{\text {hitung }}$ variabel komitmen organisasional lebih besar dari tabel maka H0 ditolak, artinya variabel komitmen organisasional berpengaruh positif terhadap variabel Kepuasan Kerja Karyawan di Novotel Bali Ngurah Rai Airport. 
Pada variabel gaya kepemimpinan diperoleh nilai $t_{\text {hitung }}=3,492$ dan $t_{\text {tabel }}=$ 2,00. Dapat disimpulkan bahwa thitung variabel gaya kepemimpinan lebih besar dari $t_{\text {tabel }}$ maka H0 ditolak, artinya variabel Gaya Kepemimpinan berpengaruh terhadap variabel Kepuasan Kerja Karyawan di Hotel Novotel Bali Ngurah Rai Airport.

Untuk melihat seberapa besar sumbangan yang diberikan oleh variabel stres kerja, komitmen organisasional, dan gaya kepemimpinan terhadap variabel kepuasan kerja karyawan, maka dapat dilihat pada tabel berikut:

Tabel 9.

Hasil Koefisien Determinasi

\begin{tabular}{ll}
\hline Model & R Square \\
\hline 1 & 0,734 \\
\hline Sumber: Data diolah, 2018 &
\end{tabular}

Dari tabel diatas maka dapat dilihat bahwa nilai R Square 0,734 yang menunjukan bahwa kontribusi atau sumbangan pengaruh variabel Stres Kerja, komitmen organisasional, dan gaya kepemimpinan terhadap variabel Kepuasan Kerja Karyawan sebesar 73,4\%, sementara sisanya 26,6\% merupakan kontribusi dari variabel-variabel lain yang tidak termasuk dalam penelitian.

Stres adalah tanggapan psikologis dari seseorang terhadap tekanan dari lingkungannya, dimana penekannyaberupa peristiwa atau situasi eksternal yang dapat membahayakan. Stres kerja diukur melalui beban kerja, sikap pemimpin, waktu kerja, komunikasi, dan tanggung jawab.

Hasil analisis data menunjukkan bahwa stres kerja berpengaruh negatif terhadap variabel kepuasan kerja karyawan di Hotel Novotel Bali Ngurah Rai Airport, hal ini sesuai dengan hipotesis satu $\left(\mathrm{H}_{1}\right)$ bahwa stres kerja berpengaruh negative terhadap kepuasan kerja karyawan. Hasil penelitian ini sesuai dengan 
hasil penelitian sebelumnya yang dilakukan oleh Afrizal dkk. (2014), Dewi dkk. (2014), dan Wibowo dkk. (2015) yang mendapatkan hasil bahwa stres kerja berpengaruh negatif terhadap kepuasan kerja karyawan.

Semakin rendah stres kerja yang dirasakan karyawan di Hotel Novotel Bali Ngurah Rai Airport maka semakin tinggi kepuasan kerja yang dirasakan oleh karyawan karena karyawan merasa beban kerja yang mereka rasakan tidak melebihi standar yang telah ditetapkan. Begitu pula sebaliknya, jika semakin tinggi stres kerja yang dirasakan, maka akan semakin rendah kepuasan kerja yang dirasakan oleh karyawan.

Komitmen organisasional merupakan suatu keadaan di mana karyawan memihak dan perduli pada organisasi tertentu dengan tujan-tujuannya serta berniat memelihara keanggotaannya dalam organisasi tersebut. Komitmen organisasional diukur melalui komitmen afektif, komitmen berkesinambungan, dan komitmen normatif.

Hasil analisis data menunjukkan bahwa komitmen organisasional berpengaruh positif terhadap variabel kepuasan kerja karyawan di Hotel Novotel Bali Ngurah Rai Airport, hal ini sesuai dengan hipotesis dua $\left(\mathrm{H}_{2}\right)$ bahwa komitmen organisasional berpengaruh positif terhadap kepuasan kerja karyawan. Hasil penelitian ini sesuai dengan hasil penelitian sebelumnya yang dilakukan oleh Baraba dkk. (2014), Okubanjo (2014) dan Arifah dan Romadhon (2015) yang mendapatkan hasil bahwa komitmen organisasional berpengaruh positif terhadap kepuasan kerja karyawan. 
Semakin rendah stres kerja yang dirasakan karyawan di Hotel Novotel Bali Ngurah Rai Airport maka semakin tinggi kepuasan kerja yang dirasakan oleh karyawan karena karyawan merasa beban kerja yang mereka rasakan tidak melebihi standar yang telah ditetapkan. Begitu pula sebaliknya, jika semakin tinggi stres kerja yang dirasakan, maka akan semakin rendah kepuasan kerja yang dirasakan oleh karyawan.

Gaya kepemimpinan adalah pola perilaku atau cara yang dipilih dan dipergunakan pemimpin dalam mempengaruhi pikiran, perasaan, sikap dan perilaku par anggota bawahannya agar mau bekerja sama untuk mencapai tujuan organisasi.

Hasil analisis data menunjukkan bahwa gaya kepemimpinan berpengaruh positif terhadap variabel kepuasan kerja karyawan di Hotel Novotel Bali Ngurah Rai Airport, hal ini sesuai dengan hipotesis dua $\left(\mathrm{H}_{2}\right)$ bahwa gaya kepemimpinan berpengaruh positif terhadap kepuasan kerja karyawan. Hasil penelitian ini sesuai dengan hasil penelitian sebelumnya yang dilakukan oleh Safitri dkk. (2012), Arzi dan Farahbod (2014), dan Machumu dan Kaitila (2014). Semakin baik gaya kepemimpinan yang diterapkan karyawan di Hotel Novotel Bali Ngurah Rai Airport maka semakin tinggi kepuasan kerja yang dirasakan oleh karyawan karena karyawan merasa termotivasi, merasa diikutsertakan dalam pengambilan keputusan serta dapat menjalin hubungan yang baik dengan atasan. Begitu pula sebaliknya, jika semakin buruk gaya kpemimpinan yang diterapkan, maka akan semakin rendah kepuasan kerja yang dirasakan oleh karyawan. 
Penelitian ini dapat memberikan informasi penting bagi Hotel Novotel Bali Ngurah Rai Airport untuk dapat meningkatkan kepuasan kerja karyawannya. Berdasarkan hasil penelitian, stres kerja berpengaruh negatif terhadap kepuasan kerja karyawan, hal ini berarti perusahaan diharapkan agar mempertahankan stres kerja berupa beban kerja, sikap pemimpin, waktu kerja, komunikasi dan tanggung jawab sehingga dapat meningkatkan kepuasan kerja karyawan. Hasil penelitian selanjutnya yaitu komitmen organisasional berpengaruh positif terhadap kepuasan kerja karyawan, hal ini perusahaan harus mempertahankan atau meningkatkan komitmen afektif, komitmen bersinambung dan komitmen normatif sehingga karyawan merasa nyaman dan dapat meningkatkan kepuasan kerja karyawan. Hasil penelitian terakhir yaitu gaya kepemimpinan berpengaruh positif terhadap kepuasan kerja karyawan, hal ini berarti perusahaan diharapkan agar mempertahankan atau meningkatkan budaya berupa norma-norma dan nilai-nilai yang diterapkan di perusahaan tetap terjaga sehingga dapat meningkatkan komitmen karyawan untuk tetap tinggal di perusahaan.

\section{SIMPULAN DAN SARAN}

Berdasarkan hasil analisis yang telah diuraikan mengenai pengaruhstres kerja, komitmen organisasional, dan gaya kepemimpinan terhadap kepuasan kerja karyawan pada Hotel Novotel Bali Ngurah Rai Airport, maka diperoleh simpulan stres kerja berpengaruh negatif terhadap kepuasan kerja karyawan yang artinya semakin tinggi stres kerja yang dirasakan oleh karyawan, maka semakin rendah kepuasan kerja karyawan untuk tetap berorganisasi di perusahaan. 
Komitmen organisasional berpengaruh positif terhadap kepuasan kerja karyawan yang artinya semakin baik komitmen organisasonal yang diterapkan pada perusahaan, maka semakin tinggi kepuasan kerja karyawan untuk tetap berkomitmen di dalam perusahaan.

Gaya kepemimpinan berpengaruh positif terhadap kepuasan kerja karyawan yang artinya semakin baik gaya kepemimpinan yan di terapkan dalam suatu perusahaan, maka semakin tinggi kepuasan kerja karyawan untuk tetap berorganisasi di perusahaan.

Saran-saran yang dapat disampaikan adalah agar dapat meningkatkan dan menjaga kepuasan kerja karyawan, maka manajemen perusahaan sebaiknya memperhatikan banyakya beban kerja kayawan dalam mengurangi beban kerja dengan cara menambah jumlah karyawan sehingga karyawan merasa beban kerja yang mereka rasakan dapat terkurangi. Agar dapat meningkatkan dan menjaga kepuasan kerja karyawan, maka sebaiknya manajemen perusahaan meningkatkan kesetiaan dan rasa bangga karyawan dengan cara memberikan penghargaan kepada karyawan yang berdedikasi lebih untuk perusahaan dengan begitu diharapkan para karyawan memiliki rasa komitmen yang tinggi untuk perusahaan.

Agar dapat meningkatkan dan menjaga kepuasan kerja karyawan, manajemen perusahaan perlu memperhatikan pentingnya pegawasan pemipin terhadap kinerja para karyawannya.

\section{REFERENSI}

Afrizal, P. R., Mochammad A. M., \& Ika, R. (2014). Pengaruh konflik kerja dan stres kerja terhadap kepuasan kerja: studi pada karyawan PT. TASPEN (PERSERO) Cabang Malang. Jurnal Administrasi Bisnis. 8(1): 1-10. 
Ardana, I Komang., Ni Wayan Mujiati., \& I Wayan Mudiartha Utama. (2012). Manajemen Sumber Daya Manusia. Yogyakarta: Graha Ilmu.

Arifah, D.A \& Romadhon, C. (2015). Pengaruh komitmen organisasi, komitmen profesional, dan gaya kepemimpina terhadap kepuasan kerja dengan motivasi sebagai variabel intervening. Conference in Business, Accounting, and Management. 2(1):357-369.

Arzi, S \& Farahbod, L. (2014). The impact of leadership style on job satisfaction: A Study of Iranian Hotels. Published by Institute of Interdisciplinary Business Research. 6(3): 171-186.

Baraba, R., Utami, E. R., \& Wijayanti. (2014). Pengaruh komitmen organisasi dan lingkungan kerja terhadap kepuasan kerja karyawan Universiitas Muhammadiyah Purworejo dengan keyakinan diri sebagai variabel pemoderasi. Segmen Jurnal dan Bisnis. 10(01): 63-77.

Beloor, V., Nanjundeswaraswamy, T. S., \& Swamy, D. R. (2017). Employee commitment and quality of work life -a literature review. The International Journal of Indian Psychology. 4(2): 175-188.

Dewi, C. N. C., I Wayan Bagia., \& Gede Putu Agus Jana Susila. (2014). Pengaruh stres kerja dan kepuasan kerja terhadap kinerja karyawan pada bagian tenaga penjualan UD. Surya Raditya Negara. E-Journal Bisma Universitas Pendidikan Ganesha. 2(1): 1-12.

Dhania, D. R. (2010). Pengaruh stres kerja dan beban kerja terhadap kepuasan kerja (studi pada Medical Representatip di Kota Kudus). Jurnal Psikologi Universitas Maria Kudus. 1(1): 16-23.

Fajriyah, S., \& Prasetya, R. J. (2015). Pengaruh gaya kepemimpinan dan lingkungan kerjaterhadap kepuasan kerja karyawan (studi kasus pada PT. Bank Central Asia, Tbk. Cabang Utama Cikarang, Jawa Barat). Jurnal Ilmiah Manajemen dan Bisnis. 1(3): 32-48.

Handoko, T. H. (2014). Manajemen Personalia dan Sumber Daya Manusia. Yogyakarta: BPFE-Yogyakarta.

Hasibuan, M. S. P. (2014). Manajemen Sumber Daya Manusia. Jakarta: Bumi Aksara.

Machumu, H. J., \& Mafwimbo M. K. (2014). Influence of leadership styles on teachers' job satisfaction: a case of selected Primary Schools in Songea and Morogoro Districts, Tanzania. International Journal of Educational Administration and Policy Studies. 6(4): 53-61.

Malik, M. E., Rizwan Q.D., \& Yasin, M. (2012). The impact of pay and promotion on job satisfaction: Evidence from higher educations institutes of Pakistan. American Journal of Economics. 10(5): 6-9. 
Meyer, J. P., \& Allen, N. J. (1997). A three-component conceptualization of organizational commitment. Human Resource Management Review.

Murty, W. A \& Gunasti, H. (2013). Pengaruh kompensasi, motivasi dan komitmen organisasional terhadap kinerja karyawan bagian akuntansi (studi kasus pada Perusahaan Manufaktur di Surabaya). The Indonesian Accounting Review. 2(2): 215-228.

Okubanjo, A.O. (2014). Organizational commitment and job satisfaction as determinant of primary school teachers turnover intention. Higher Education of Social Science. 7(1): 172-179.

Plangiten, P. (2013). Gaya kepemimpinan dan lingkungan kerja pengaruhnya terhadap kepuasan kerja karyawan pada PT. Pos Indonesia (Persero) Manado. Jurnal EMBA. 1(4): 44-58.

Priansa, D. J. (2014). Perencanaan \& Pengembangan SDM. Bandung: Alfabeta.

Robbins, S. P., \& Judge, T.A. (2017). Perilaku Organisasi. Edisi 16. Jakarta: Selemba Empat.

Safitri, H. M., Amri \& Shabri, M. (2012). Pengaruh gaya kepemimpinan, kerjasama tim, dan gaya komunikasi terhadap kepuasan kerja serta dampaknya terhadap kinerja pegawai pada Sekretariat Daerah kota Sabang. Jurnal Ilmu Manajemen Pascasarjana Universitas Syiah Kuala. 1(2): 1-17.

Shurbagi, A. M. A. (2014). The relationship between transformational leadership and organizational commitment in National Oil Corporation of Libya. 3rd International of Humanities, Economics and Geography. 3(7): 85-91.

Sinambela, L. P. (2016). Manajemen Sumber Daya Manusia. Jakarta: PT Bumi Aksara

Spagnoli, P., \& Antonio, C. (2012). Personality and organisational commitment: The mediating role of job satisfaction during socialization. Career Development International. 17(3): 255-275.

Styawahyuni, A., \& Yuniari. (2014). Pengaruh pemberdayaan karyawan dan stres kerja terhadap kepuasan kerja karyawan. E-Jurnal Manajemen Universitas Udayana. 6(5): 1590-1603.

Sutrisno, E. (2014). Manajemen Sumber Daya Manusia. Jakarta : Kencana

Umar, H. (2012). Desain Penelitian MSDM dan Perilaku Karyawan. Jakarta : PT. Raja Grafindo Persada.

Velnampy, T \& Aravinthan. S. A. (2013). Occupational stress and organizational commitment in Private Banks: A Sri Lankan Experience. European Journal of Business and Management. 5(7): 78-99. 
E-Jurnal Manajemen, Vol. 8, No. 9, 2019 :5344-5371

Wibowo, I Gede Putro., Gede Riana., \& Made Surya Putra. (2015). Pengaruh stres kerja terhadap kepuasan kerja dan komitmen organisasional karyawan. EJurnal Ekonomi Dan Bisnis Universitas Udayana. 4(2): 125-140.

Zainal, V. R., Muliaman, D. H., \& Mansyur, R. H. (2014). Kepemimpinan dan Perilaku Organisasi. Edisi Keempat. Jakarta: PT. Raja Grafindo Persada. 